University of Nebraska - Lincoln

DigitalCommons@University of Nebraska - Lincoln

\title{
Comparison of Ground-Based Remote Sensors for Evaluation of Corn Biomass Affected by Nitrogen Stress
}

\author{
Soon-Dal Hong \\ Chungbuk National University \\ James Schepers \\ United States Department of Agriculture, Agricultural Research Service, james.schepers@gmail.com \\ Dennis D. Francis \\ University of Nebraska-Lincoln, dfrancis1@unl.edu \\ Michael R. Schlemmer \\ University of Nebraska-Lincoln, michael.schlemmer@bayer.com
}

Follow this and additional works at: https://digitalcommons.unl.edu/usdaarsfacpub

Part of the Agricultural Science Commons

\begin{abstract}
Hong, Soon-Dal; Schepers, James; Francis, Dennis D.; and Schlemmer, Michael R., "Comparison of GroundBased Remote Sensors for Evaluation of Corn Biomass Affected by Nitrogen Stress" (2007). Publications from USDA-ARS / UNL Faculty. 589.

https://digitalcommons.unl.edu/usdaarsfacpub/589
\end{abstract}

This Article is brought to you for free and open access by the U.S. Department of Agriculture: Agricultural Research Service, Lincoln, Nebraska at DigitalCommons@University of Nebraska - Lincoln. It has been accepted for inclusion in Publications from USDA-ARS / UNL Faculty by an authorized administrator of DigitalCommons@University of Nebraska - Lincoln. 


\title{
Comparison of Ground-Based Remote Sensors for Evaluation of Corn Biomass Affected by Nitrogen Stress
}

\author{
Soon-Dal Hong \\ Department of Agricultural Chemistry, Chungbuk National University, \\ Cheongju, Chungbuk, Republic of Korea

\section{J. S. Schepers, D. D. Francis, and M. R. Schlemmer} \\ United States Department of Agriculture-Agricultural Research Service \\ and Department of Agronomy and Horticulture, University of Nebraska, \\ Lincoln, Nebraska, USA
}

\begin{abstract}
The nondestructive determination of plant biomass is not possible; however, crop-canopy sensors that determine the normalized difference vegetation index have the potential to estimate living biomass, which is indicative of plant vigor and stress. Pot experiments using sand culture were conducted in 2002 and 2003 under greenhouse conditions to evaluate the effect of nitrogen $(\mathrm{N})$ deficiency on corn biomass and reflectance. Stress was imposed by implementing six to eight levels of $\mathrm{N}$ in Hoagland's nutrient solution. Canopy reflectance measurements made at three growth stages with a variety of handheld spectral sensors (active and passive) were closely correlated with dry weight and chlorophyll meter readings of corn at flowering, as well as at the two earlier growth stages. Results indicate that selected ground-based sensors and related reflectance indexes can provide a nondestructive, real-time assessment of apparent plant $\mathrm{N}$ status and thus be used for in-season $\mathrm{N}$-management decisions.
\end{abstract}

Keywords: Biomass, nitrogen, reflectance, sensor

Received 17 January 2006, Accepted 18 October 2006

Address correspondence to J. S. Schepers, United States Department of AgricultureAgricultural Research Service and Department of Agronomy and Horticulture, University of Nebraska, 113 Keim Hall, Lincoln, NE 68583-0915, USA. E-mail: jschepers1@unl.edu 


\section{INTRODUCTION}

Research and technological advances in the field of remote sensing have greatly enhanced the ability to detect and quantify physical and biological stresses that affect the productivity of agricultural crops. Recently, researchers have evaluated remote-sensing techniques for estimating the nitrogen $(\mathrm{N})$ status of growing crops by determining the appropriate wavelength or combination of wavelengths to characterize crop N deficiency (Gitelson, Girtz, and Merzlyak 2003; Schlemmer et al. 2005). Reflectance in specific visible and near-infrared regions of the electromagnetic spectrum has proved useful in detection of plant stresses that can sometimes be related to nutrient deficiencies after additional evaluation. The spectral quality of light reflected from leaves has long been relied upon as an indicator of plant stress and crop vigor. The spectral characteristics of radiation that is reflected, transmitted, or absorbed by leaves can provide specific information about the physiological response to growth conditions and plant adaptations to the environment. It is commonly reported that plant leaves have a low reflectance in the visible spectral region because of strong absorption by chlorophyll and relatively high reflectance of near-infrared radiation because of internal leaf scattering. Several studies have shown good relationships among spectral reflectance, chlorophyll content, and $\mathrm{N}$ status in green vegetation (Blackmer et al. 1996a). Vegetation indexes provide a very simple yet elegant method for extracting the green plant quantity signal from complex canopy spectra. The use of reflectance ratios to analyze spectra has allowed the identification of reflectance bands corresponding to the absorption bands of specific pigments (Chappelle, Kim, and McMurtrey 1992). Many indexes computed as differences, ratios, or linear combinations of reflectance in visible and near infrared (NIR) wavebands (Richardson and Wiegand 1977; Tucker 1979; Wiegand et al. 1991) have been used for evaluation of various vegetation parameters. Sometimes these index values can be misleading when multiple stresses occur (Schepers et al. 1996). Multispectral vegetation indices derived from crop-canopy reflectance data in relatively wide wavebands can be used to monitor the growth response of plants in relation to environmental factors. Specifically, ground-based crop-canopy sensors can measure the amount of light reflected from nearby surfaces such as leaf tissue or soil and are in contrast to aircraft or satellite platforms that generate photographs or various types of digital images.

The most common indexes utilize red and near-infrared canopy reflectance in the form of ratios such as normalized difference vegetation index $(\mathrm{NDVI})$ (Tucker 1979), where NDVI $=(\mathrm{NIR}-\mathrm{Red}) /(\mathrm{NIR}+\mathrm{Red})$ or in linear combination such as with the perpendicular vegetation index (Richardson and Wiegand 1977). The basis of this relationship is the strong absorption (low reflectance) of red light by chlorophyll and low absorption (high reflectance and transmittance) in the NIR by green leaves. These indexes have been found to be well correlated with 
various vegetation parameters including green leaf area, biomass, percentage of green cover, productivity, and photosynthetic activity (Hatfield, Asrar, and Kanemasu 1984; Sellers 1985). Many researchers have used high-resolution satellite imagery to calculate NDVI values and thereby assess the health and condition of crops and natural vegetation over large geographical regions (Roderick, Smith, and Cridland 1996; Roderick, Smith, and Ladwick 1996). Thereafter, researchers have proposed other indices such as the soil adjusted vegetation index (SAVI; Huete 1988), optimized soil adjusted vegetation index (OSAVI; Rondeaux, Steven, and Baret 1996), and transformed soil adjusted vegetation index (TSAVI; Baret, Guyot, and Major 1989) for assessing crop vegetation due to confounding soil background effects in the measurement. The green normalized difference vegetation index (GNDVI), where the green band is substituted for the red band in the NDVI equation, has been shown to be more useful for assessing canopy variation in green crop biomass related to $\mathrm{N}$ fertility status of soils (Gitelson and Merzlyak 1996, 1997; Shanahan et al. 2001).

Availability of soil-test indexes in semi-arid areas is frequently limited and depends on many environmental factors, whereas plant tests such as reflectance indexes can be used for more consistent evaluation of crop biomass because they integrate across all of the environmental factors and management practices (Schepers 2001). Remote sensing techniques, in particular, multispectral visible and NIR reflectance, can provide an instantaneous, nondestructive, and semiquantitative assessment of the crop biomass. The situation is that many of the crop-sensing tools and techniques noted previously are not well suited for greenhouse studies or commercial operations where one or even a few plants are involved. As such, there are many greenhouse and commercial hot-house operations where the managers could benefit from some type of nondestructive assessment of things such as size, biomass, color, and disease. It is fully recognized that singleplant observations made by sensors need to be carefully scrutinized, yet certain types of measurements can reveal meaningful relative differences within or between plant canopies. Certain types of measurements related to turf management are able to detect the onset of disease or stress well before the symptoms are visible, so perhaps some of the same sensing approaches and methods of data analysis would be useful for single-plant observations? Single-plant or small-scale sensing presents a significant challenge to sensor technologies because of background differences (brightness of soil, etc.) and the confounding effect thus have on reflectance measured by a sensor.

The goal of this study was to compare several analytical devices ranging in cost and sophistication for making single-plant measurements of vegetative biomass and evaluate the related reflectance indexes for corn as affected by $\mathrm{N}$ stress. A secondary goal was to identify potential problems and limitations when using sensors in greenhouses and single-plant applications. 


\section{MATERIALS AND METHODS}

\section{General Procedure}

Pot experiments involving sand culture were conducted in 2002 and 2003 in a greenhouse to evaluate corn biomass production. Sand was placed in large $(28-\mathrm{cm}$ dia $\times 26-\mathrm{cm}$ depth) free-draining polyvinyl chloride (PVC) pots. Each pot was put in a plastic container $(35$-cm width $\times 50$-cm length $\times 28$ $\mathrm{cm}$ depth) that was covered with Styrofoam ${ }^{\circledR}$ to exclude light and inhibit algae growth. Corn was sown on 1 October 2002 with Pioneer brand hybrid 33G27 and on 1 March 2003 with Pioneer brand hybrid 3417. After planting, $1 \mathrm{~L}$ of water was applied to the surface of the sand, and $2 \mathrm{~L}$ were placed in the catch container to wet the sand from the bottom. After 2 weeks, the catch container was emptied, and the same wetting process was repeated with half-strength nutrient solution with modified N. Nitrogen stress was imposed by providing eight levels of $\mathrm{N}$ in Hoagland's nutrient solution in 2002 (50\% to 120\%) and six levels in 2003 (40\% to 140\%) (Table 1). After another 2 weeks, the watering procedure was modified to full-strength nutrient solution, except for the $\mathrm{N}$ modification, and replaced weekly until the flowering growth stage (11 December 2002 and 8 May 2003).

Three plants were initially established in each pot with the plan to sequentially harvest one plant at $\mathrm{V}_{6 \sim 7}$, another at $\mathrm{V}_{8 \sim 9}$, and the last one at flowering. Spectral measurements involved all plants in a given pot on a given date, but only one plant was sacrificed for dry-matter determination at each sampling date. Biomass calculations were adjusted accordingly. Pots with corn plants were arranged in a randomized complete block design with three replications in 2002 and four replications in 2003. To minimize the environmental effects on plant growth, pots within a replication were arranged in a $2 \times 4$ or $2 \times 3$ grid. Positions were randomly changed daily, and each pot was rotated clockwise by 90 degrees daily. Pots of each replication were exchanged with another every week.

\section{Sensors}

Plant measurements were made using 1) chlorophyll meter (Minolta, SPAD $502),{ }^{1}$ 2) Fieldscout ${ }^{\mathrm{TM}}$ (Spectrum Technologies, CM1000), 3) GreenSeeker $^{\mathrm{TM}}$ (Ntech Industries), 4) Crop Circle ${ }^{\mathrm{TM}}$ (Holland Scientific), and 5) spectroradiometers (Analytical Spectral Device Inc. in 2002; Ocean Optics S2000 and USB2000 in 2003). The SPAD meter uses two light-emitting diodes (650 and $940 \mathrm{~nm}$ ) to determine the amount of light transmitted through a $2-\times 3-\mathrm{mm}$ leaf section. This device basically measures potential photosynthesis in that excess light is provided to the enclosed leaf section, and

\footnotetext{
${ }^{1}$ Mention of commercial products is for the benefit of readers and does not imply endorsement by USDA-ARS.
} 
Table 1. Application amount of nutrients in the plot of $100 \% \mathrm{~N}$ treatment

\begin{tabular}{|c|c|c|}
\hline Nutrient & 2002 experiment $\left(\mathrm{mg} \mathrm{L}^{-1}\right)$ & 2003 experiment $\left(\mathrm{mg} \mathrm{L}^{-1}\right)$ \\
\hline $\mathrm{N}$ & $210\left(\mathrm{NH}_{4} \mathrm{NO}_{3}+\mathrm{KNO}_{3}\right)$ & $200\left(\mathrm{KNO}_{3}+\mathrm{Ca}\left(\mathrm{NO}_{3}\right)_{2} \times 4 \mathrm{H}_{2} \mathrm{O}\right)$ \\
\hline $\mathrm{P}$ & $31\left(\mathrm{~K}_{2} \mathrm{HPO}_{4}\right)$ & $20\left(\mathrm{KH}_{2} \mathrm{PO}_{4}\right)$ \\
\hline K & $235\left(\mathrm{~K}_{2} \mathrm{HPO}_{4}, \mathrm{KNO}_{3}+\mathrm{KCl}\right)$ & $243\left(\mathrm{KNO}_{3}+\mathrm{KH}_{2} \mathrm{PO}_{4}\right)$ \\
\hline $\mathrm{Ca}$ & $200\left(\mathrm{CaSO}_{4}+\mathrm{Ca}\left(\mathrm{NO}_{3}\right)_{2} \times 4 \mathrm{H}_{2} \mathrm{O}\right)$ & $175\left(\mathrm{Ca}\left(\mathrm{NO}_{3}\right)_{2} \times 4 \mathrm{H}_{2} \mathrm{O}\right)$ \\
\hline $\mathrm{Mg}$ & $20\left(\mathrm{MgSO}_{4} \times 7 \mathrm{H}_{2} \mathrm{O}\right)$ & $25\left(\mathrm{MgSO}_{4} \times 7 \mathrm{H}_{2} \mathrm{O}\right)$ \\
\hline $\mathrm{Fe}$ & 1.36 (FeNa EDTA) & 7.33 (FeNa EDTA) \\
\hline $\mathrm{Mn}$ & $0.50\left(\mathrm{MnSO}_{4} \times \mathrm{H}_{2} \mathrm{O}\right)$ & $0.25\left(\mathrm{MnSO}_{4} \times \mathrm{H}_{2} \mathrm{O}\right)$ \\
\hline B & $0.50\left(\mathrm{H}_{3} \mathrm{BO}_{3}\right)$ & $0.26\left(\mathrm{H}_{3} \mathrm{BO}_{3}\right)$ \\
\hline $\mathrm{Cl}$ & $1.77(\mathrm{KCl})$ & $7.00(\mathrm{NaCl})$ \\
\hline $\mathrm{Zn}$ & $0.05\left(\mathrm{ZnSO}_{4} \times 7 \mathrm{H}_{2} \mathrm{O}\right)$ & $0.05\left(\mathrm{ZnSO}_{4} \times 7 \mathrm{H}_{2} \mathrm{O}\right)$ \\
\hline $\mathrm{Cu}$ & $0.02\left(\mathrm{CuSO}_{4} \times 5 \mathrm{H}_{2} \mathrm{O}\right)$ & $0.01\left(\mathrm{CuSO}_{4} \times 5 \mathrm{H}_{2} \mathrm{O}\right)$ \\
\hline Mo & $0.01\left[\left(\mathrm{NH}_{4}\right) 6 \mathrm{Mo} 7 \mathrm{O} 24 \times 4 \mathrm{H}_{2} \mathrm{O}\right]$ & $0.01\left[\left(\mathrm{NH}_{4}\right)_{6} \mathrm{Mo}_{7} \mathrm{O}_{24} \times 4 \mathrm{H}_{2} \mathrm{O}\right]$ \\
\hline $\mathrm{S}$ & $100.7\left(\mathrm{M}-\mathrm{SO}_{4}\right)+24.0\left(\mathrm{H}_{2} \mathrm{SO}_{4}\right)$ & $33.0\left(\mathrm{M}-\mathrm{SO}_{4}\right)$ \\
\hline
\end{tabular}

transmittance is compared to that when no leaf is present. The Fieldscout ${ }^{\mathrm{TM}}$ chlorophyll meter commercialized by Spectrum Technologies Inc. uses ambient and reflected light at 700 and $840 \mathrm{~nm}$ to estimate chlorophyll content. Dual laser beams in the meter define an open, conical field of view when the trigger is pressed. The meter does not contact the leaf but is assumed to be equally accurate at distances ranging from 28 to $183 \mathrm{~cm}$ (1.1- to 18.8-cm-dia. field of view, respectively) from the target.

The GreenSeeker ${ }^{\mathrm{TM}}$, as commercialized by Ntech Industries Inc., was the only active sensor used in this study and measures red and near-infrared (NIR) reflectance to generate a normalized difference vegetation index (NDVI). The field of view for this sensor is $1 \times 60 \mathrm{~cm}$ with an effective depth of field from $\sim 70$ to $120 \mathrm{~cm}$ ( 28 to 48 inches) from the target. The Crop Circle ${ }^{\mathrm{TM}}$ sensor, made by Holland Scientific Inc., is a multiwaveband sensor designed for measuring light reflecting from crop canopies. Crop Circle ${ }^{\mathrm{TM}}$ is a passive sensor with a conical field of view (20 degrees) that measures fourband reflectance; blue $(440 \mathrm{~nm} \pm 10 \mathrm{~nm})$, green $(550 \mathrm{~nm} \pm 10 \mathrm{~nm})$, red $(680 \mathrm{~nm} \pm 10 \mathrm{~nm})$, and near infrared (NIR, $800 \mathrm{~nm} \pm 65 \mathrm{~nm})$, allowing the calculation of NDVI and green NDVI. Spectroradiometers measured reflectance from visible to NIR wavebands; $350-2500 \mathrm{~nm}$ (1-nm interval) for Analytical Spectral Devices Inc., 350-1025 nm (0.3-nm interval) for Ocean Optics S2000, and 400-996 nm (2-nm interval) for Ocean Optics USB2000. Consequently, a wide variety of vegetation indices can be calculated.

\section{Measurements}

Average SPAD readings were obtained from 15 measurements on the uppermost expanded leaf for each plant that was destructively sampled. The 
CM1000 chlorophyll meter was positioned nadir to a leaf and between the target and sun to record incident and reflected light. Reflectance measurements with the CM1000 were obtained from the same leaf as the SPAD measurement. Canopy reflectance measurements with the GreenSeeker ${ }^{\mathrm{TM}}$ and Crop Circle $^{\mathrm{TM}}$ sensors and spectroradiometers (ASD Inc. and Ocean optics S2000 and USB2000) were made on the same date as the SPAD and CM1000 measurements. All leaf reflectance measurements were made during midday under incident solar radiation from an angle perpendicular to the canopy. To minimize the background effect on reflectance measured with GreenSeeker ${ }^{\mathrm{TM}}$, Crop Circle ${ }^{\mathrm{TM}}$, and spectroradiometers, a large black board was installed on the surface of each pot.

In the case of GreenSeeker ${ }^{\mathrm{TM}}$ measurements, the sensor was slowly scanned over the corn canopy of each pot, keeping about $100 \mathrm{~cm}$ from the plane of the canopy to the sensor. About 40 data points were recorded for each corn canopy. Data representing background reflectance obtained from start and end of the sensor scanning were omitted. Finally, about 20-25 available data per pot were included in the calculation of an average. Measurements with the Crop Circle ${ }^{\mathrm{TM}}$ sensor (more than 30 data per pot) were made outdoors with the sensor installed $60-70 \mathrm{~cm}$ above the top of the canopy. Measurements with ASD Inc. and Ocean Optics S2000 spectroradiometers were similar to the measurements with the Crop Circle sensor except that three scans were averaged for each pot. In some cases, the Ocean Optics USB2000 spectroradiometer was connected to a contact probe from which reflectance was measured at eight positions on leaves 8 and 9 (16 total). Values for NDVI and GNDVI were calculated using reflectance values for the appropriate wavebands. The normalized difference vegetation index, NDVI $=(\mathrm{NIR}-$ Red)/(NIR + Red), was originally proposed as a means of estimating living biomass. The green normalized difference vegetation index (GNDVI), where GNDVI $=($ NIR - Green $) /($ NIR + Green $)$ was suggested by Gitelson and Merzlyak (1996). The wavelengths (blue, green, red, and NIR wavebands) used for calculating reflectance indices from spectroradiometer measurements were selected at the peak of the correlation coefficient curve between reflectance and chlorophyll content or dry weight of corn tissue (Figure 1). After collecting canopy reflectance measurements, two leaf discs were taken from the uppermost expanded leaf using a cork borer (1-cm dia.) for determination of chlorophyll content. Leaf disc samples were homogenized in $80 \%$ acetone solution, and the mixture was centrifuged at $2000 \mathrm{rpm}$ for $2 \mathrm{~min}$. Thereafter, the optical density of supernatant was measured at 645 and $663 \mathrm{~nm}$. Chlorophyll content was calculated using the Arnon method (1949).

\section{RESULTS AND DISCUSSION}

Dry weight of corn tissue varied by three to four times or more in response to $\mathrm{N}$ availability for all sampling dates (Table 2). The greatest differences occurred at 


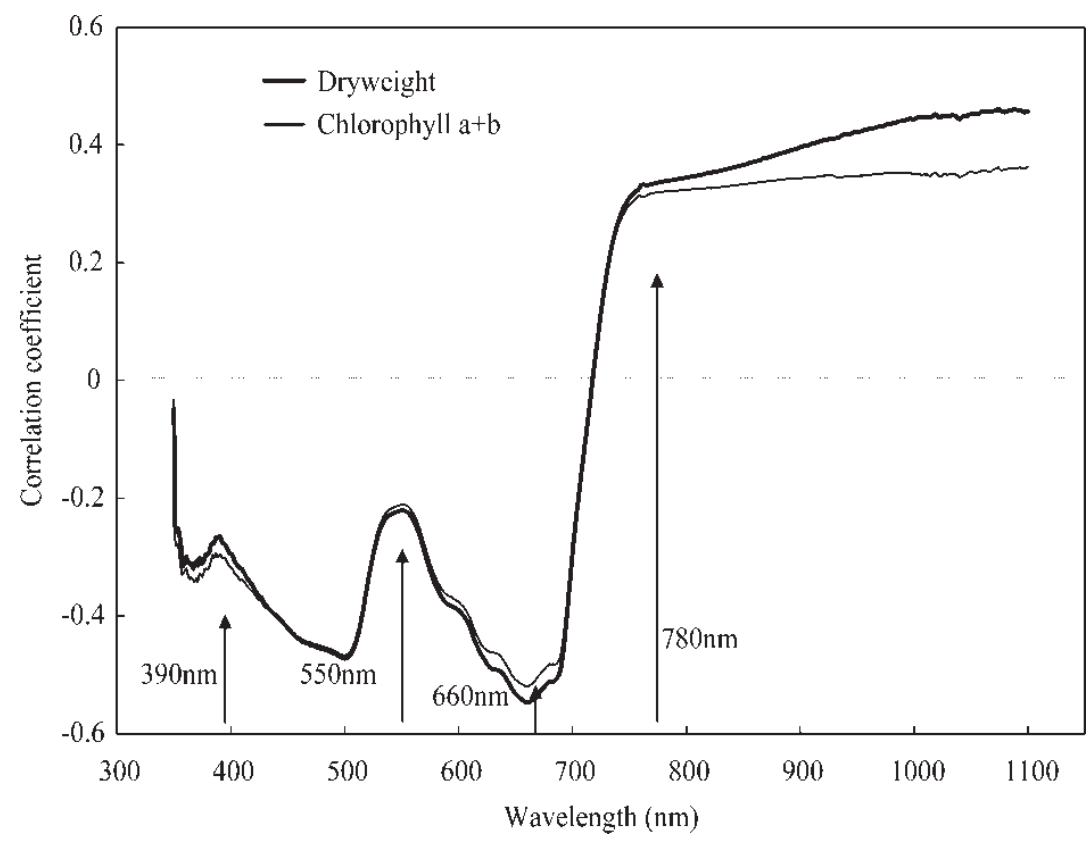

Figure 1. Correlation coefficient between canopy reflectance and dry weight and/or content of chlorophyll $\mathrm{a}+\mathrm{b}$ at the $\mathrm{V}_{8-9}$ growth stage.

the flowering stage where biomass ranged from 24.1 to $95.5 \mathrm{~g} \mathrm{plant}^{-1}$ for 2002 and from 8.3 to $101.7 \mathrm{~g} \mathrm{plant}^{-1}$ for 2003 . Variations of corn dry matter for 2002 and 2003 experiments showed the coefficient of variation (CV) across the range of $\mathrm{N}$ treatments was at least $30 \%$ for all sampling data, thus representing a wide range in plant sizes for spectral analyses.

Canopy reflectance patterns in general were typical for $\mathrm{N}$-stressed plants (Figure 2). In the visible part of the spectrum, 350 to $700 \mathrm{~nm}$, differences in

Table 2. Variation of dry weight of corn $\left(\mathrm{g}\right.$ plant $\left.^{-1}\right)$ affected by $\mathrm{N}$ stress $(\mathrm{n}=24)$

\begin{tabular}{lrcccccc}
\hline & \multicolumn{3}{c}{ 2002 experiment } & & \multicolumn{3}{c}{2003 experiment } \\
\cline { 2 - 5 } \cline { 7 - 8 } Statistic & $\mathrm{V}_{6-7}$ stage & $\mathrm{V}_{8-9}$ stage & Flowering & & $\mathrm{V}_{6}$ stage & $\mathrm{V}_{7-8}$ stage & Flowering \\
\hline Min. & 7.1 & 11.2 & 24.1 & & 4.1 & 7.6 & 8.3 \\
Max. & 21.6 & 44.2 & 95.5 & & 14.9 & 37.9 & 101.7 \\
Median & 14.2 & 24.8 & 46.2 & & 8.8 & 19.0 & 51.5 \\
Average & 13.2 & 24.7 & 48.2 & & 8.7 & 20.3 & 51.7 \\
STDEV $^{a}$ & 4.1 & 8.1 & 19.0 & & 2.6 & 7.6 & 23.9 \\
CV $(\%)^{3}$ & 31.3 & 33.0 & 39.5 & & 30.2 & 37.5 & 46.3 \\
\hline
\end{tabular}

${ }^{a}$ STDEV: Standard deviation. 


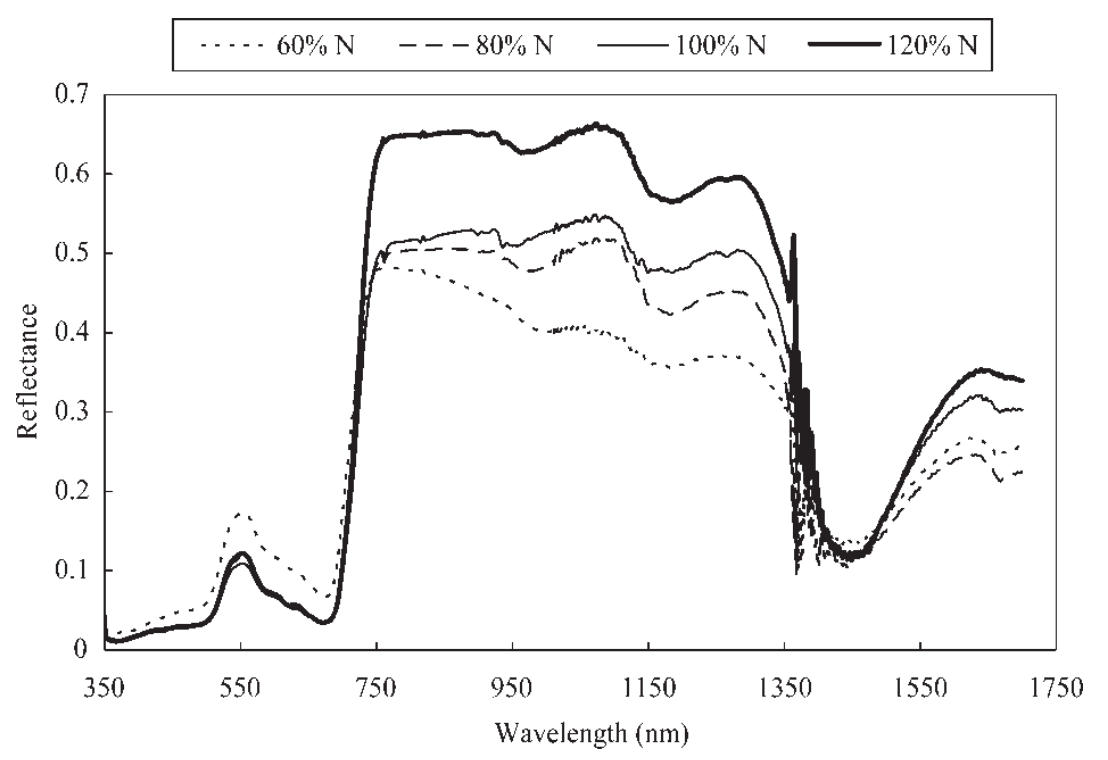

Figure 2. Hyperspectral reflectances for corn canopy affected by $\mathrm{N}$ stress at the $\mathrm{V}_{8-9}$ growth stage for the 2002 experiment.

reflectance attributed to $\mathrm{N}$ rate were greatest at about $550 \mathrm{~nm}$ (green region). Canopy reflectance in the red-edge region $(700 \mathrm{~nm}$ ) showed little visual difference even though significant numerical differences existed. Reflectance in the NIR region increased as expected and showed the greatest separation at the highest $\mathrm{N}$ rate. These results are consistent with those of Schepers (2001), who reported that nearly all nutrient stresses influence the chlorophyll status of the crop and are most easily detected in the green band, with less general sensitivity in the red band. Gausman and Allen (1973) compared representative spectral characteristics for 30 different plant species and observed that reflectance is generally low in the visible wavelengths, increases rapidly at $700 \mathrm{~nm}$, and remains high until $1300 \mathrm{~nm}$, after which it begins to decrease as shown in Figure 2. Generally, reflectance, transmittance, and absorbance corresponded most precisely with chlorophyll concentrations at wavelengths near $700 \mathrm{~nm}$, although their correlations were also strong in the 550 to $625 \mathrm{~nm}$ range (Cater and Spiering 2002; Cater and Knapp 2001). Green plant leaves typically display very low reflectance and transmittance in visible regions of the spectrum (400 to $700 \mathrm{~nm}$ ) because of strong absorptance by photosynthetic and accessory plant pigments (Chappelle, Kim, and McMurtrey 1992; Pinter et al. 2003). By contrast, reflectance and transmittance are both usually high in the NIR regions (700 to $1300 \mathrm{~nm}$ ) because there is very little absorption by subcellular particles or pigments and also because there is considerable scattering at the mesophyll-cell wall interface (Gausman 1974, 1977; Jensen 2000; Slaton, Hunt, and Smith 2001). 
Correlation coefficients between dry weight of corn tissue and vegetation indices derived from reflectance measurements are shown in Tables 3 and 4 for the 2002 and 2003 experiments, respectively. All correlations in 2002, except for the CM 1000 meter at the $\mathrm{V}_{6-7}$ sampling, were similarly significant with dry weight. The poor performance of the CM1000 chlorophyll meter is attributed to the difficulty in properly positioning the meter between the sun and the leaf under greenhouse conditions. In contrast, the SPAD chlorophyll meter showed good correlation with dry weight (Tables 3 and 4) and chlorophyll content (Figure 3). From the relationship between chlorophyll reading and chlorophyll content, it was assumed that the SPAD reading could be used for the calibration standard of chlorophyll in the absence of chlorophyll content data. Others have also found that the SPAD 502 chlorophyll meter readings correlate linearly with extractable chlorophyll concentrations for a wide variety of crops, including rice (Takebe et al. 1990), soybean (Ma, Morrison, and Voldeng 1995), and corn (Blackmer and Schepers 1995). Schepers (2001) found that within a corn hybrid, there was usually a strong positive correlation between leaf chlorophyll content and $\mathrm{N}$ concentration and a similar strong relationship between SPAD readings and both leaf chlorophyll and N concentrations.

The NDVI values determined by GreenSeeker ${ }^{\mathrm{TM}}$ and Crop Circle ${ }^{\mathrm{TM}}$ sensors were highly correlated with dry weight at the $\mathrm{V}_{6-7}$ growth stage in 2002 ( $r=0.79$ and 0.78, respectively) (Table 3). Data collected in 2003 showed similar results across sampling dates for most techniques (Table 4). Each of the vegetation indices derived by GreenSeeker ${ }^{\mathrm{TM}}$ and Crop

Table 3. Correlation coefficient between dry weight of corn and several vegetation indexes for 2002 experiemnt $(\mathrm{n}=24)$

\begin{tabular}{|c|c|c|c|c|}
\hline Measurement & Index & $\mathrm{V}_{6-7}$ stage & $\mathrm{V}_{8-9}$ stage & Flowering \\
\hline Arnon's method & Chlorophyll $\mathrm{a}+\mathrm{b}$ & $0.84^{* *}$ & $0.77^{* *}$ & \\
\hline $\begin{array}{l}\text { Chlorophyll meter } \\
\text { (SPAD502) }\end{array}$ & $\begin{array}{l}\text { Chlorophyll } \\
\text { reading }\end{array}$ & $0.84^{* *}$ & $0.85^{* *}$ & $0.59^{* *}$ \\
\hline $\begin{array}{l}\text { Chlorophyll meter } \\
\text { (CM1000) }\end{array}$ & $\begin{array}{l}\text { Chlorophyll } \\
\text { reading }\end{array}$ & 0.32 & $0.63^{* *}$ & \\
\hline GreenSeeker & NDVI & $0.79^{* *}$ & $0.63^{* *}$ & $0.81^{* *}$ \\
\hline GreenSeeker & Red/NIR & $-0.76^{* *}$ & $-0.64^{* *}$ & $-0.79^{* *}$ \\
\hline Crop Circle & NDVI & $0.78^{* *}$ & & \\
\hline Crop Circle & Red/NIR & $-0.78^{* *}$ & & \\
\hline Crop Circle & GNDVI & $0.82^{* *}$ & & \\
\hline Spectroradiometer, ASD & NDVI & & $0.46^{*}$ & \\
\hline Spectroradiometer, ASD & Red/NIR & & $-0.44^{*}$ & \\
\hline Spectroradiometer, ASD & GNDVI & & $0.68^{* *}$ & \\
\hline
\end{tabular}

*Significant at the 0.05 level.

** Significant at the 0.01 level. 
Table 4. Correlation coefficient between dry weight of corn and several vegetation indexes for 2003 experiment $(\mathrm{n}=24)$

\begin{tabular}{|c|c|c|c|c|}
\hline \multirow[b]{2}{*}{ Measurement } & \multirow[b]{2}{*}{ Index } & \multicolumn{3}{|c|}{ Dry weight } \\
\hline & & $\mathrm{V}_{6}$ stage & $\mathrm{V}_{7-8}$ stage & Flowering \\
\hline Arnon's method & Chlorophyll $\mathrm{a}+\mathrm{b}$ & $0.65^{* *}$ & $0.50^{*}$ & \\
\hline Chlorophyll meter & SPAD reading & $0.73^{* *}$ & $0.83^{* *}$ & $0.59^{* *}$ \\
\hline GreenSeeker $^{\mathrm{TM}}$ & NDVI & $0.68^{* *}$ & $0.70^{* *}$ & \\
\hline GreenSeeker $^{\mathrm{TM}}$ & Red/NIR & $-0.66^{* *}$ & $-0.69^{* *}$ & \\
\hline Crop Circle ${ }^{\mathrm{TM}}$ & NDVI & $0.87^{* *}$ & $0.83^{* *}$ & $0.88^{* *}$ \\
\hline Crop Circle ${ }^{\mathrm{TM}}$ & GNDVI & $0.80^{* *}$ & $0.82^{* *}$ & $0.86^{* *}$ \\
\hline Crop Circle ${ }^{\mathrm{TM}}$ & Vegetative cover ${ }^{a}$ & $0.69^{* *}$ & $0.73^{* *}$ & $0.84^{* *}$ \\
\hline Crop Circle ${ }^{\mathrm{TM}}$ & Red/NIR & $-0.86^{* *}$ & $-0.82^{* *}$ & $-0.87^{* *}$ \\
\hline Crop Circle ${ }^{\mathrm{TM}}$ & $\begin{array}{l}(\text { NIR }- \text { Green }) / \\
(\text { Green })\end{array}$ & $0.80^{* *}$ & $0.82^{* *}$ & $0.86^{* *}$ \\
\hline $\begin{array}{l}\text { Spectroradiometer, } \\
\text { S2000 }\end{array}$ & NDVI & 0.38 & $0.42^{*}$ & \\
\hline $\begin{array}{l}\text { Spectroradiometer, } \\
\text { S2000 }\end{array}$ & GNDVI & $0.43^{*}$ & $0.59^{* *}$ & \\
\hline $\begin{array}{l}\text { Spectroradiometer, } \\
\text { S2000 }\end{array}$ & Vegetative cover & 0.27 & 0.25 & \\
\hline $\begin{array}{l}\text { Spectroradiometer, } \\
\text { S2000 }\end{array}$ & Red/NIR & -0.36 & $-0.41^{*}$ & \\
\hline $\begin{array}{l}\text { Spectroradiometer, } \\
\text { USB } 2000\end{array}$ & NDVI & $0.54^{* *}$ & $0.65^{* *}$ & \\
\hline $\begin{array}{l}\text { Spectroradiometer, } \\
\text { USB2000 }\end{array}$ & GNDVI & $0.47^{*}$ & 0.21 & \\
\hline $\begin{array}{l}\text { Spectroradiometer, } \\
\text { USB } 2000\end{array}$ & Vegetative cover & $0.53^{* *}$ & $0.58^{* *}$ & \\
\hline $\begin{array}{l}\text { Spectroradiometer, } \\
\text { USB2000 }\end{array}$ & Red/NIR & $-0.54^{* *}$ & $-0.65^{* *}$ & \\
\hline
\end{tabular}

* Significant at the 0.05 level.

${ }^{* *}$ Significant at the 0.01 level.

${ }^{a}$ Vegetative cover: $($ Green - Red $) /($ Green + Red - Blue $)$.

Circle ${ }^{\mathrm{TM}}$ provided a good prediction of corn biomass at the $\mathrm{V}_{6}, \mathrm{~V}_{7-8}$, and flowering growth stage, whereas all the indices derived from spectroradiometer data showed lower correlation coefficients. One possible explanation for the low correlations between biomass and spectroradiometer-based data is that these measurements represent an average of a few spot readings over the canopy. In contrast, Crop Circle and GreenSeeker measurements represent the integration of a scan across the entire canopy involving many individual measurements.

It should be noted that chlorophyll measurements (SPAD and analytical) do not incorporate any direct measure of plant architecture, so it is rather 


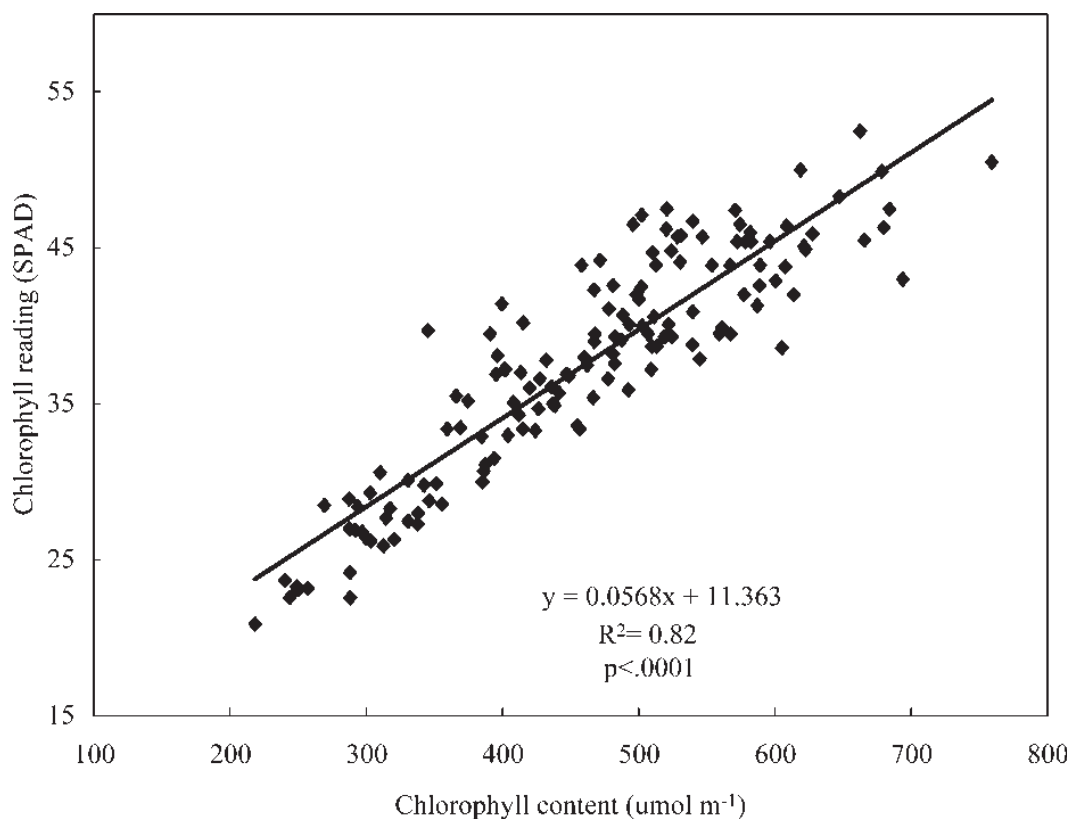

Figure 3. Relationship between chlorophyll content and chlorophyll reading (SPAD) at the $\mathrm{V}_{4}, \mathrm{~V}_{6-7}$, and $\mathrm{V}_{8-9}$ growth stages for the same leaf measured in the 2002 experiment.

remarkable that such a single determination can be extrapolated from a small area on a leaf to represent a characteristic of the entire plant. Spectroradiometer measurements were less highly correlated to dry matter than SPAD data, but this might be expected in that the data they provide do not include a measure of leaf thickness, as do the chlorophyll techniques (e.g., leaf thickness influences both SPAD readings and chlorophyll concentration). Except for SPAD and chlorophyll content data, all sensor measurements represent an integration of instantaneous reflectance values from the vegetation in total.

Regression analysis of Crop Circle and GreenSeeker data identified as being significant in Table 4 revealed a curvilinear relationship between biomass and NDVI (Figure 4). Apparently, situations with higher amounts of biomass also have an increased tendency for reflectance from some leaves to be blocked by others (i.e., multiple layers). This observation is considered an important finding in that it indicates a possible depth limit within the canopy for light reflectance. For both sampling dates, the passive Crop Circle sensor performed better than the active GreenSeeker sensor. Further analysis with the Crop Circle sensor involving other wavebands (i.e., green and NIR) showed a similar curvilinear relationship between biomass and GNDVI for both growth stages (Figure 5). Pot measurements, as in this study, did not involve enough biomass to represent a closed canopy, so 


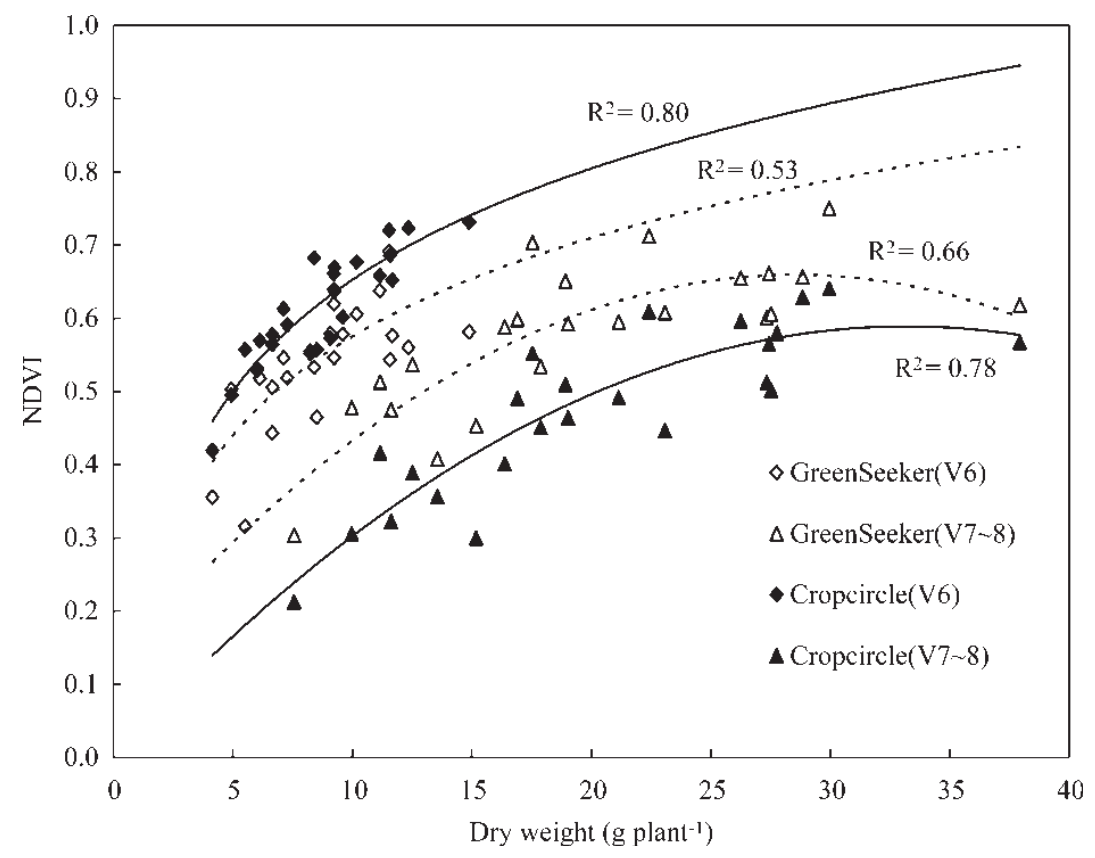

Figure 4. Relationship between dry weight and NDVI by different sensors at the $\mathrm{V}_{6}$ and $\mathrm{V}_{7-8}$ growth stages of corn for the 2003 experiment.

estimation of biomass using canopy sensors is likely limited to the upper five to six layers of leaves.

Theoretically, GNDVI should be more highly correlated with chlorophyll content than NDVI for situations with a leaf area index (LAI) greater than 2.0 (Gitelson and Merzlyak 1996; Gitelson, Gritz, and Merzylak 2003). This hypothesis is supported by Blackmer et al. (1996b), who showed that canopy radiance near $550 \mathrm{~nm}$ and $710 \mathrm{~nm}$ was superior to canopy radiance near $450 \mathrm{~nm}$ or $650 \mathrm{~nm}$ for detecting $\mathrm{N}$ deficiencies after the crop started growing rapidly. For lower LAI situations, leaf tissue and chlorophyll content are insufficient to absorb a majority of the red light. In the case of this study, LAI at $\mathrm{V}_{7-8}$ was $<2.0$, so SPAD readings were compared with both NDVI and GNDVI to evaluate the appropriateness of each index. Although the slopes of the linear regressions were different, the coefficients of determination for the $\mathrm{V}_{6}$ and $\mathrm{V}_{7-8}$ growth stages in 2003 ranged from 0.73 to 0.77 (Figure 6). A recent publication by Gitelson and Merzlyak (2004) noted that when red reflectance saturates at a low value because of abundant vegetation and NIR reflectance reaches a high plateau level, NDVI calculations become insensitive to leaf chlorophyll status. They proposed a green index $[(\mathrm{NIR}-$ green $) /($ green $)]$ that was highly correlated with LAI. Data from the 2003 experiment were analyzed using the 


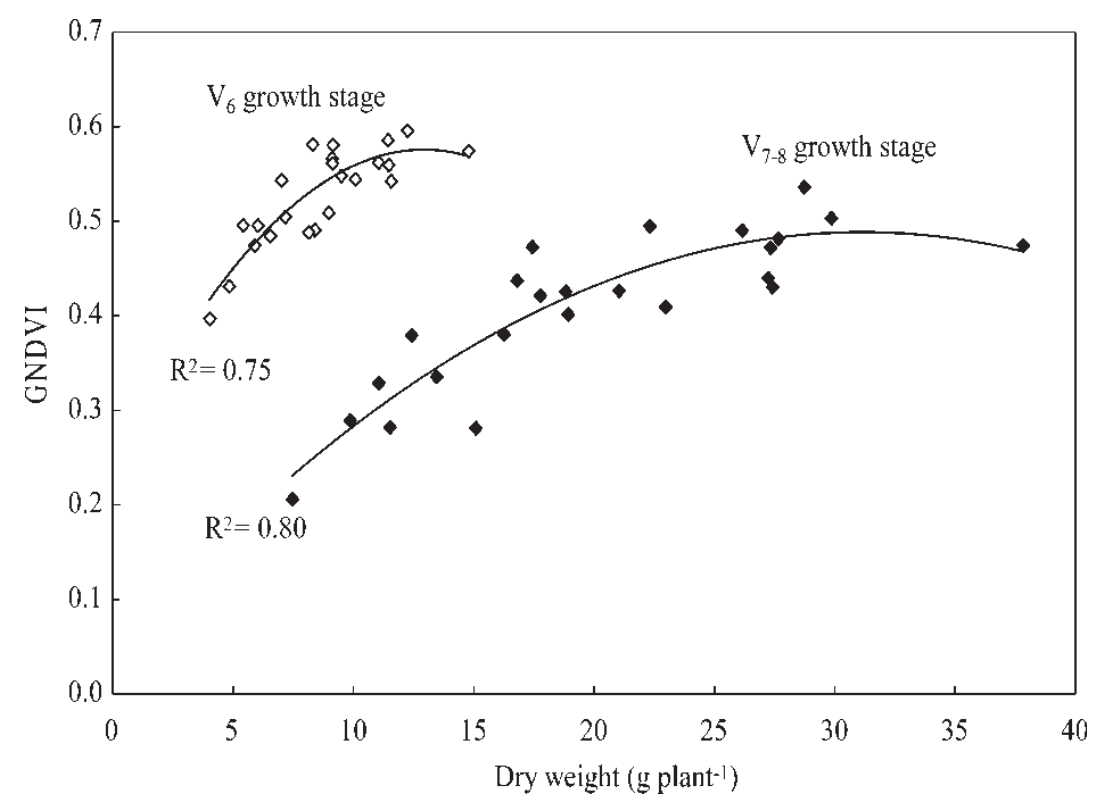

Figure 5. Relationship between dry weight and GNDVI by Crop Circle at the $\mathrm{V}_{6}$ and $\mathrm{V}_{7-8}$ growth stages of corn for the 2003 experiment.

proposed green index and found to be well correlated $\left(r^{2}=0.77\right.$ and 0.74 at the $V_{6}$ and $V_{7-8}$ growth stages, respectively) with SPAD readings (Figure 7).

The influence of leaf orientation and area in the sensor's field of view was nicely illustrated when a potted corn plant was centered on a rotary table and reflectance measurements were taken in 45-degree increments. The greatest effect was observed with the GreenSeeker because of its narrow field of view (Figure 8). Using a fan to simulate a field breeze only had minimal influence on sensor output. Scanning across plants, as would be the situation when driving through a field, would tend to capture all attributes of the vegetation. However, orientation of the leaves relative to the sensor's field of view could have a significant effect on the variability of sensor output, depending on the rate of travel (i.e., how many plants are scanned each $0.1 \mathrm{~s}$ in the case of the GreenSeeker).

Extrapolating sensor readings, and related vegetation indices, from early in the life cycle of a crop into the future to estimate LAI, biomass production, or grain yield is of interest to producers and consultants. Over time, researchers have utilized NDVI or similar indexes to evaluate LAI, chlorophyll concentration, N concentration, and yield of cotton (Hong et al. 2001; Tarpley, Reddy, and Sassenrath-Cole 2000; Wiegand et al. 1991; Read et al. 2002), soybean (Ma et al. 2001), wheat (Wiegand et al. 1990, 1992; Aparicio et al. 2002; Mullen et al. 2003), turf grass (Bell et al. 2002), and corn (Blackmer 


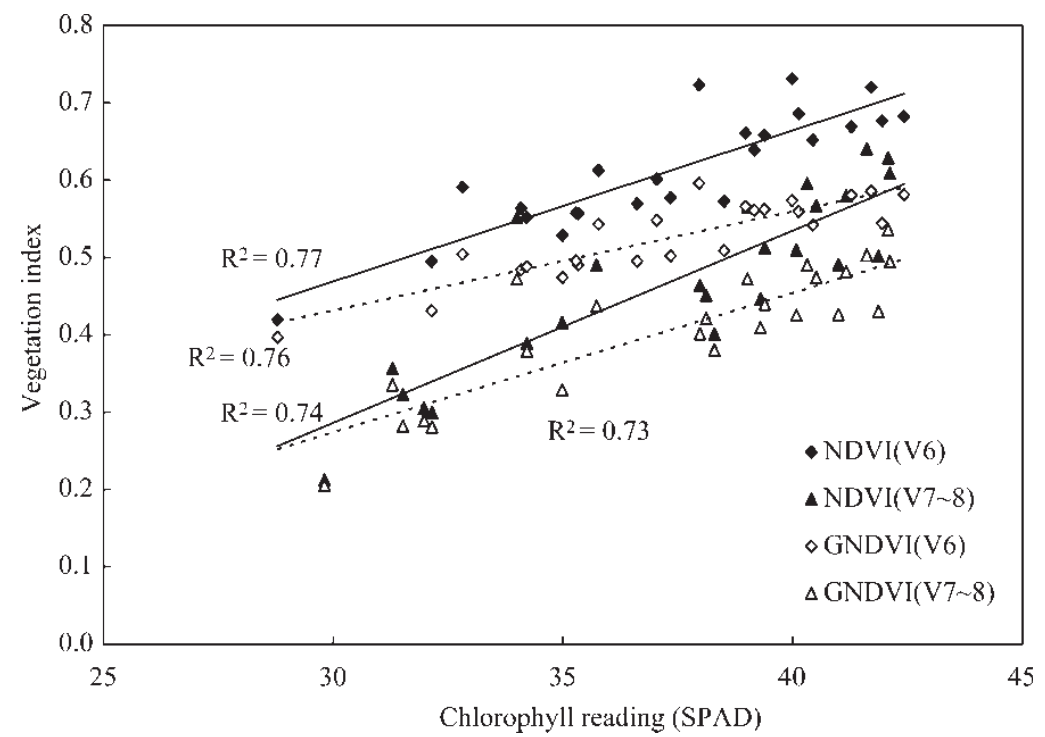

Figure 6. Relationship between chlorophyll readings (SPAD) and vegetation indexes by Crop Circle at the $V_{6}$ and $V_{7-8}$ growth stages of corn for the 2003 experiment.

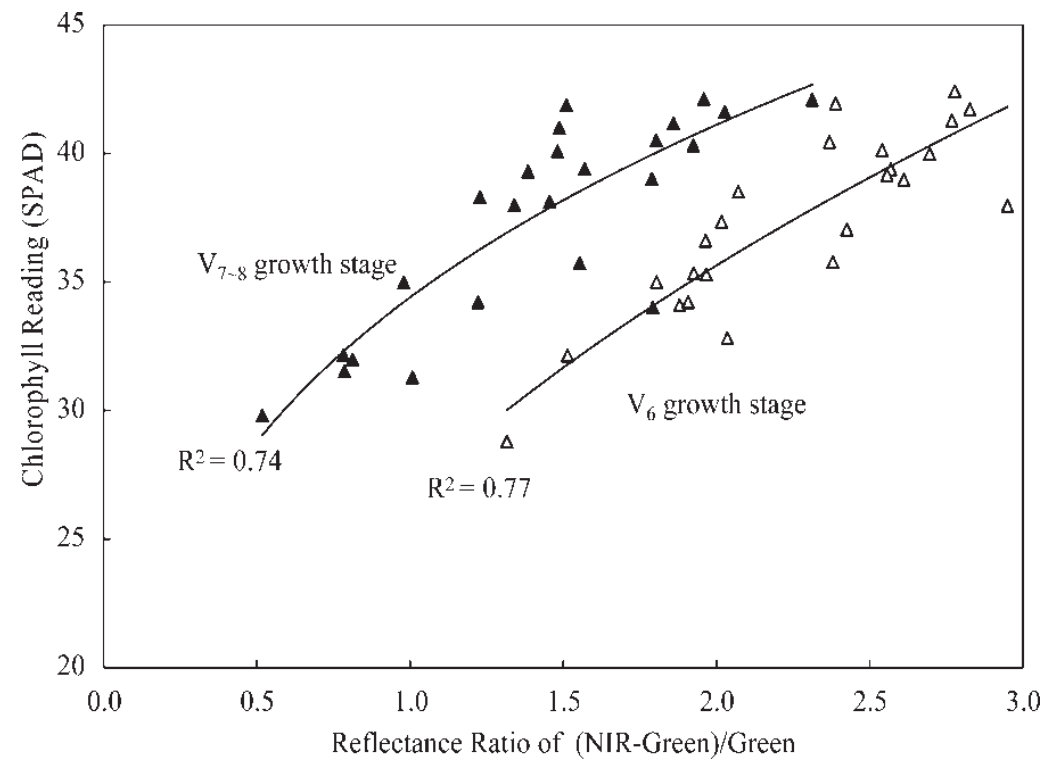

Figure 7. Relationship between chlorophyll readings (SPAD) and reflectance ratio of (NIR-Green)/Green. 


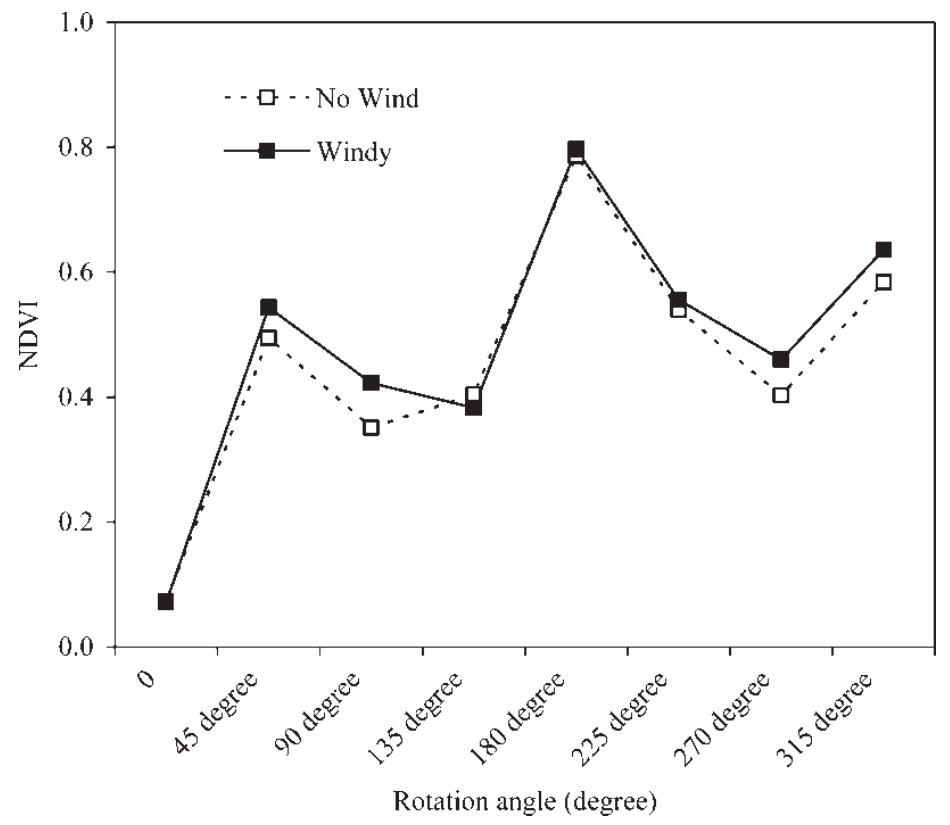

Figure 8. NDVI by GreenSeeker measurement affected by rotation angle and windy condition of corn plants.

et al. 1996b; Shanahan et al. 2001; Osborne et al. 2002a, 2002b; Haboudane et al. 2002). In several cases, scientists noted that relationships progressively improved as the measurement approached maturity of the crop. Although the plants in this study were not grown to maturity, measures of crop vigor (i.e., NDVI, GNDVI, and vegetative cover) at two preceding growth stages were highly correlated with biomass production at flowering (Table 5). As with other studies noted previously, the significance of the correlation improved as the time between the sensor measurement and the measured plant parameter decreased.

\section{SUMMARY}

Several nondestructive plant measurement techniques were evaluated in terms of estimating biomass production. SPAD chlorophyll meter measurements were highly correlated with leaf chlorophyll content and plant dry weight. Measurements made with sensors that integrate reflectance as the sensor passes over the canopy (e.g., Crop Circle and GreenSeeker) were more highly correlated with biomass than the average of a series of spot measurements made with spectroradiometer devices. Results of this study showed superior performance of the passive sensor compared to the active sensor to 
Table 5. Correlation coefficient between dry weight at the flowering stage and Crop Circle indexes at the different growth stage for the 2003 experiment

\begin{tabular}{llc}
\hline Growth stage & $\begin{array}{c}\text { Index by Crop } \\
\text { Circle }\end{array}$ & $\begin{array}{c}\text { Dry weight at the } \\
\text { flowering stage }\end{array}$ \\
\hline $\mathrm{V}_{6}$ stage & NDVI & $0.72^{* *}$ \\
& GNDVI & $0.66^{* *}$ \\
& $\mathrm{VC}^{a}$ & $0.71^{* *}$ \\
$\mathrm{~V}_{7-8}$ stage & NDVI & $0.82^{* *}$ \\
& GNDVI & $0.81^{* *}$ \\
Flowering stage & VC & $0.71^{* *}$ \\
& NDVI & $0.88^{* *}$ \\
& GNDVI & $0.86^{* *}$ \\
& VC & $0.84^{* *}$ \\
\hline
\end{tabular}

* Significant at the 0.05 level.

** Significant at the 0.01 level.

${ }^{a} \mathrm{VC}$ stands for vegetative cover.

estimate biomass, but this observation could be an artifact in that the field of view is different for the two types of sensors and design is very different. Active sensors have the advantage of being easier to use under changing or low-light conditions, so compromises must be made to fit the local situation. Advances in active sensor technologies should significantly increase the applicability for field and greenhouse operations.

\section{REFERENCES}

Aparicio, V., N.D., Araus, J.L., Casadesus, J., and Royo, C. (2002) Relationship between growth traits and spectral vegetation indices in durum wheat. Crop Sci., 42: $1547-1555$.

Arnon, D.J. (1949) Copper enzymes in isolated chloroplasts: Polyphenoloxidases in Beta vilgaris. Plant Phys., 24: 1-15.

Baret, F., Guyot, G., and Major, D.J. (1989) TSAVI: A vegetation index which minimizes soil brightness effects on LAI and APAR estimation. In Proc. IGARSS '89 Can. Symp. Remote Sensing; Vancouver, Canada, 1355-1358.

Bell, G.E., Martin, D.L., Stone, M.L., Solie, J.B., and Johnson, G.V. (2002) Turf area mapping using vehicle-mounted optical sensors. Crop Sci., 42: 648-651.

Blackmer, T.M. and Schepers, J.S. (1995) Use of a chlorophyll meter to monitor N status and schedule fertigation of corn. J. Prod. Agric., 8: 56-60.

Blackmer, T.M., Schepers, J.S., Varvel, G.E., and Meyer, G.E. (1996a) Analysis of aerial photography for nitrogen stress within corn fields. Agron. J., 88: 729-733.

Blackmer, T.M., Schepers, J.S., Varvel, G.E., and Walter-Shea, E.A. (1996b) Nitrogen deficiency detection using reflected short wave radiation from irrigated corn canopies. Agron. J., 88: 1-5. 
Cater, G.A. and Knapp, A.K. (2001) Leaf optical properties in higher plants: Linking spectral characteristics to stress and chlorophyll concentration. Amer. J. Bot., 88: 677-684.

Cater, G.A. and Spiering, B.A. (2002) Optical properties of intact leaves for estimating chlorophyll concentration. J. Environ. Qual., 31: 1424-1432.

Chappelle, E.W., Kim, M.S., and McMurtrey, J.E. (1992) Ratio analysis of reflectance spectra (RARS): An algorithm for remote estimation of the concentrations of chlorophyll A, chlorophyll B, and carotenoids in soybean leaves. Remote Sensing Environ., 39: $239-247$.

Gausman, H.W. (1974) Leaf reflectance of near-infrared. Photogrammetric Engin. Remote Sensing, 40: 183-191.

Gausman, H.W. (1977) Reflectance of leaf components. Remote Sensing Environ., 6: $1-9$.

Gausman, H.W. and Allen, W.A. (1973) Optical parameters of leaves of 30 plant species. Plant Physiol., 52: 57-62.

Gitelson, A., Gritz, U., and Merzlyak, M.N. (2003) Relationships between leaf chlorophyll content and spectral reflectance and algorithms for non-destructive chlorophyll assessment in higher plant leaves. J. Plant Phys., 160: 271-282.

Gitelson, A.A. and Merzlyak, M.N. (1996) Signature analysis of leaf reflectance spectra: Algorithm development for remote sensing of chlorophyll. J. Plant Phys., 148: 494-500.

Gitelson, A.A. and Merzlyak, M.N. (1997) Remote estimation of chlorophyll content in higher plant leaves. Intl. J. Remote Sensing, 18: 291-298.

Gitelson, A. and Merzlyak, M.N. (2004) Non-destructive assessment of chlorophyll, carotenoids and anthocyanin content in higher plant leaves: Principles and algorithms. In Remote Sensing for Agriculture and the Environment; Stamatiadis, S., Lynch, J., and Schepers, J.S. (eds.); Peripheral Editions: Larissa, Greece, 78-94.

Haboudane, D., Miller, J.R., Tremblay, N., Zarco-Tejada, P.J., and Dextraze, L. (2002) Integrated narrow-band vegetation indices for prediction of crop chlorophyll content for application to precision agriculture. Remote Sensing Environ., 81: 416-426.

Hatfield, J.L., Asrar, G., and Kanemasu, E.T. (1984) Intercepted photosynthetically active radiation estimated by spectral reflectance. Remote Sensing Environ., 14: $65-75$.

Hatfield, J.L. and Pinter, P.J., Jr. (1993) Remote sensing for crop protection. Crop Protection, 12: 403-413.

Hong, L., Lascano, R.J., Barnes, E.M., Booker, J., Wilson, L.T., Bronson, K.F., and Segarra, E. (2001) Multispectral reflectance of cotton related to plant growth, soil water and texture, and site elevation. Agron. J., 93: 1327-1337.

Huete, A.R. (1988) A soil-adjusted vegetation index (SAVI). Remote Sensing Environ., 25: $295-309$.

Jensen, J.R. (2000) Remote Sensing of the Environment: An Earth Resource Perspective; Upper Prentice-Hall: Saddle River, N.J.

Ma, B.L., Dwyer, L.M., Costa, C., Cober, E.R., and Morrison, M.J. (2001) Early prediction of soybean yield from canopy reflectance measurements. Agron. J., 93: $1227-1234$.

Ma, B.L., Morrison, M.J., and Voldeng, H.D. (1995) Leaf greenness and photosynthetic rates in soybean. Crop Sci., 35: 1411-1414.

Mullen, R.W., Freeman, K.W., Raun, W.R., Johnson, G.V., Stone, M.L., and Soli, J.B. (2003) Identifying an in-season response index and the potential to increase wheat yield with nitrogen. Agron. J., 95: 347-351. 
Osborne, S.L., Schepers, J.S., Francis, D.D., and Schlemmer, M.R. (2002a) Use of spectral radiance to estimate in-season biomass and grain yield in nitrogen- and water-stressed corn. Crop Sci., 42: 165-171.

Osborne, S.L., Schepers, J.S., Francis, D.D., and Schlemmer, M.R. (2002b) Determining specific wavelengths of spectral radiance measurements to detect phosphorus and nitrogen deficiencies in corn. Agron. J., 94: 1215-1221.

Pinter, P.J., Jr., Hatfield, J.L., Schepers, J.S., Barens, E.M., Moran, M.S., Daughtry, C.S.T., and Upchurch, D.R. (2003) Remote sensing for crop management. Photogrammetric Engineering Remote Sensing, 69: 647-664.

Read, J.J., Tarpley, L., McKinion, J.M., and Reddy, K.R. (2002) Narrow-waveband reflectance ratios for remote estimation of nitrogen status in cotton. J. Environ. Qual., 31: 1442-1452.

Richardson, A.J. and Wiegand, C.L. (1977) Distinguishing vegetation from soil background information. Photogrammetric Engineering Remote Sens., 43: $1541-1552$.

Roderick, M., Smith, R., and Cridland, S. (1996) The precision of the NDVI derived from AVHRR observations. Remote Sensing Environ., 56: 57-65.

Roderick, M., Smith, R., and Lodwick, G. (1996) Calibrating long-term AVHRR derived NDVI imagery. Remote Sensing Environ., 58: 1-12.

Rondeaux, G., Steven, M., and Baret, F. (1996) Optimization of soil-adjusted vegetation indices. Remote Sensing Environ., 55: 95-107.

Schepers, J.S. (2001) Practical applications of remote sensing. In Proc. InfoAg Conference, Potash and Phosphate Institute: Indianapolis, Ind.

Schepers, J.S., Blackmer, T.M., Wilhelm, W.W., and Resende, M. (1996) Transmittance and reflectance measurements of corn leaves from plants with different nitrogen and water supply. J. Plant Phys., 148: 523-529.

Schlemmer, M.S., Shanahan, J.F., Schepers, J.S., and Francis, D.D. (2005) Remotely measuring chlorophyll content in corn leaves with differing $\mathrm{N}$ and relative water content. Agron. J., 97: 106-112.

Sellers, P.J. (1985) Canopy reflectance, photosynthesis, and transpiration. Intl. J. Remote Sens., 6: 1335-1372.

Shanahan, J.F., Schepers, J.S., Francis, D.D., Varvel, G.E., Wilhelm, W.W., Tringe, J.M., Schlemmer, M.K., and Major, D.J. (2001) Use of remote-sensing imagery to estimate corn grain yield. Agron. J., 93: 583-589.

Slaton, M.R., Hunt, E.R., and Smith, W.K. (2001) Estimating near-infrared leaf reflectance from leaf structural characteristics. Amer. J. Bot., 88: 278-284.

Takebe, M., Yonesama, T., Inada, K., and Mcrakam, T. (1990) Spectral reflectance of rice canopy for estimating crop nitrogen status. Plant Soil, 122: 295-297.

Tarpley, L., Reddy, K.R., and Sassenrath-Cole, G.F. (2000) Reflectance indices with precision and accuracy in predicting cotton leaf nitrogen concentration. Crop Sci., 40: $1814-1819$.

Tucker, C.J. (1979) Red and photographic infrared linear combinations for monitoring vegetation. Remote Sensing Environ., 8: 127-150.

Wiegand, C.L., Gerbermann, A.H., Gallo, K.P., Bald, B.L., and Dusek, D. (1990) Multisite analyses of spectral-biophysical data for corn. Remote Sensing Environ., 33: $1-16$.

Wiegand, C.L., Maas, S.J., Aase, J.K., Hatfield, J.L., Pinter, P.J., Jackson, R.D., Jr., Kanemasu, E.T., and Lapitan, R.L. (1992) Multisite analyses of spectral-biophysical data for wheat. Remote Sensing Environ., 42: 1-21.

Wiegand, C.L., Richardson, A.J., Escobar, D.E., and Gerbermann, A.H. (1991) Vegetation indices in crop assessments. Remote Sensing Environ., 35: 105-119. 